\title{
HIGH LEVEL THINKING SKILLS EMPOWER STUDENTS PRIMARY EDUCATION THROUGH INNOVATIVE LEARNING
}

\section{Sajidan, Afandi}

Universitas Sebelas Maret

sajidan@fkip.uns.ac.id

\section{Article History}

accepted 30/09/2018

approved 12/10/2018

published 30/10/2018

\section{Keywords}

high level thinking skills, Innovative learning, basic education students

\begin{abstract}
To reach the stage of cognitive development is higher, one form of mental ability is a very important training to students early is high level thinking skills. If it refers to the characteristics of basic education age psychology then true learning takes place must always pay attention to these aspects in accordance with the level of mental development of the child at that age. The use of models of innovative learning such as inquiry, CLIS, and learning in the TAAC can empower high level thinking skills.
\end{abstract}

Social, Humanities, and Education Studies (SHEs): Conference Series https://jurnal.uns.ac.id/shes
p-ISSN 2620-9284 e-ISSN 2620-9292 


\section{PENDAHULUAN}

Usia pendidikan dasar (6-15 tahun) merupakan usia paling produktif dalam membentuk kecerdasan dan perilaku seseorang, karena pada usia ini sinapsis neural yang terjadi pada otak manusia mengalami pertumbuhan dan perkembangan yang pesat. Menurut teori perkembangan kognitif Piaget, anak usia pendidikan dasar mengalami transformasi mental dari tahap pra-operasional menuju operasional konkret (Schunk, 2012). Di tahap ini, terjadi transformasi mental dari perceptual menuju logikal, dari transductive menuju inductive, dan dari pola berpikir klasifikasi tunggal menuju pola berpikir multi-klasifikasi (McGregor, 2007).

Sejumlah riset di bidang neurologi dan psikologi memperkuat gagasan ini dimana pada anak usia pendidikan dasar terjadi perkembangan yang pesat pada wilayah korteks seperti prefrontal korteks dan temporal yang mengatur ingatan, sensory, dan motorik yang mengubah apa yang didengar, dilihat dan dilakukan menjadi ingatan jangka panjang dan resisten (Pinel, 2000; Clark, Boutoz, \& Mendez, 2010). Konsekuensi logisnya adalah bahwa sekolah perlu menyediakan lingkungan dan pendekatan belajar yang tepat bagi siswa untuk dapat mengembangkan dan memfasilitasi kemampuan mental secara optimal. Penyediaan lingkungan belajar yang tepat ini dianggap sebagai langkah penting dalam mendukung tahap perkembangan kognitif berikutnya.

Holyoak dan Morrison (2005) menyatakan bahwa keterampilan berpikir adalah proses mental yang terjadi ketika seseorang berusaha untuk memahami sebuah kejadian-kejadian sebagai bentuk pengalaman yang memungkinkan seseorang untuk mengintegrasikan setiap pengalaman baru ke dalam skemata yang telah ada sebelumnya agar dapat diadaptasi dan di transformasi menjadi suatu bentuk pengetahuan. Keterampilan berpikir itu sendiri oleh banyak ahli digolongkan menjadi 2 bentuk, yakni: keterampilan berpikir tingkat rendah (LOTs) yang dicirikan dengan proses mental sederhana dan mengutamakan ingatan, dan keterampilan berpikir tingkat tinggi (HOTs) yang dicirikan dengan proses mental yang saling terinterkoneksi dan bersifat multirepsentasi (Zohar, 2004; Teare, 2005).

Keterampilan berpikir seyogyanya senantiasa dilatihkan dalam pembelajaran dan guru mempertimbangkan bahwa efek dari nature (genetik atau talenta) dan nurture ( lingkungan belajar seperti: atmosfir akademik, model pembelajaran guru, dan perilaku guru) sangat kuat dalam keberhasilan pencapaian pemberdayaan keterampilan berpikir tingkat tinggi (HOTs) siswa. Hasil meta-analisis yang dilakukan oleh Budsankom et al (2015) menemukan keterkaitan langsung antara karakteristik intelegensia, psikologi, lingkungan belajar dengan HOTs dan keterkaitan tidak langsung antara karakteristik keluarga dengan pemberdayaan HOTs (Gambar 1). 


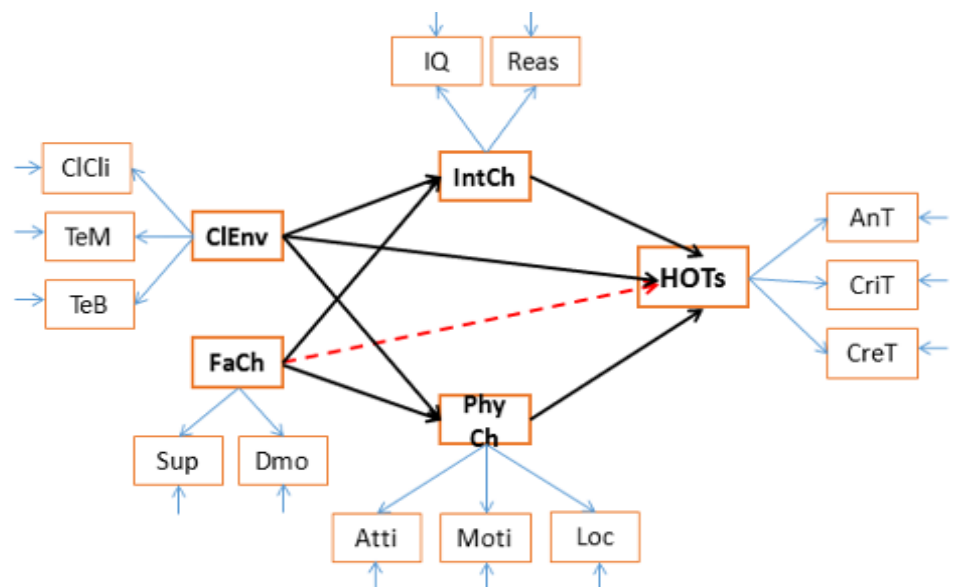

Gambar 1. Hubungan antar genetik (nature) dan lingkungan belajar (nurture), dengan keterampilan berpikir analitis, kritis dan kreatif (Budsankom et al, 2015)

Keterangan: IntCh (Intellegence Characteristics), IQ (Intelegence Quotient), Reas (Reasoning), ClEnv (Classroom Environment), ClCl (Classroom Climate), TeM(Teacher Method), TeB(Teacher Behaviour), PhyCh (Phychological Characteristic), Atti(Attitude), Moti(Motivation), Loc( Locus of Control), FaCh( Family Characteristic), Sup(Support), and Dmo(Democratic). $\rightarrow$ (pengaruh langsung) $-->$ ( pengaruh tidak langsung).

Bagaimana melatih keterampilan berpikir, khususnya HOTs pada jenjang pendidikan dasar? Jawabannya tentu terletak pada pemilihan pendekatan, model, strategi, atau metode pembelajaran yang tepat sesuai dengan karakteristik siswa usia pendidikan dasar. Jika merujuk pada karakteristik psikologi mereka yang seringkali dicirikan dengan adanya rasa ingin tahu yang tinggi, senang bermain sambil belajar, dan menyukai sesuatu hal yang baru, maka sejatinya pembelajaran yang berlangsung harus senantiasa memperhatikan aspek-aspek sesuai dengan tingkat perkembangan mental anak pada usia tersebut (Lundervold, Heiman \& Manger, 2008).

Berbagai hasil studi yang ada menunjukan seringkali pembelajaran yang berlangsung pada usia pendidikan dasar masih berkutat pada transfer pengetahuan dan cenderung mengabaikan cara bagaimana siswa bisa belajar untuk menguasai pengetahuan, masih berkutat pada guru sebagai sumber informasi (teacher oriented), dan penggunaan ceramah (rote learning) sebagai pilihan yang utama (Gutman \& Feinsten, 2008). Hal ini tentu berakibat pada pengetahuan yang diperoleh siswa SD cenderung kuat pada aspek LOTs, sedangkan HOTs masih dinilai lemah. Lemahnya HOTs pada anak usia pendidikan dasar ini perlu mendapat tanggapan serius, karena membangun keterampilan berpikir sejak dini adalah langkah awal membangun generasi masa depan yang kritis, kreatif, dan pemecah masalah yang tangguh di kehidupan bermasyarakat, berbangsa dan bernegara

\section{PEMBAHASAN}

\section{Keterampilan Berpikir Tingkat Tinggi Yang Sesuai Dengan Anak Usia Pendidikan Dasar}

Pembelajaran dalam pandangan psikologi, sejatinya pendidik wajib mempertimbangkan aspek perkembangan kognitif peserta didik. Menurut Piaget seperti yang dikutip Woolfolk (2009) perkembangan kognitif manusia dipengaruhi oleh maturasi (kematangan), aktivitas dan transmisi sosial. Maturasi merupakan perubahan 
biologis yang terprogram secara genetik yang berkaitan dengan kemampuan untuk beradaptasi dengan lingkungan dan belajar darinya. Transmisi sosial berkaitan dengan interaksi dengan lingkungan sosial dan juga belajar darinya. Keseluruhan dari aspek tersebut akan berinteraksi satu sama lain dalam membentuk kecerdasan dan kematangan berpikir seseorang.

Pandangan Piaget (dalam Wolfolk, 2009) bahwa perkembangan kognitif anak terdiri dari 4 periode utama yang berkorelasi dengan semakin matangnya penalaran seiring dengan pertambahan usia, yakni: (1) tahapan sensorimotor (usia 0-2 tahun) anak berinteraksi dengan alam dengan indera (sensori) dan tindakan (motorik); (2) tahapan praoperasional (usia 2-7 tahun), anak belajar menggunakan dan merepresentasikan objek dengan gambaran dan kata-kata menggunakan penalaran intuitif bukan logis; (3) tahapan operasional konkrit (usia 7-11 tahun), anak dapat melakukan penalaran logis menggantikan pemikiran intuitif sejauh pemikiran dapat diterapkan ke dalam contoh-contoh yang spesifik atau konkrit; dan (4) tahapan operasional formal (usia 11 tahun sampai dewasa), anak mempunyai kemampuan untuk berpikir secara abstrak, menalar secara logis, dan menarik kesimpulan dari informasi yang tersedia.

Berbeda dengan Piaget yang mengkategorikan tahapan perkembangan kognitif berdasarkan usia, Biggs dan Collins (1982) menyusun sistematika cara mendeskripsikan bagaimana performa pembelajar tumbuh dan berkembang dalam kompleksitas dan tingkatan abstraksi ketika menguasai banyak tugas di sekolah. Terdapat 5 tingkatan dalam perkembangan kognitif, yakni: (1) tahap sensori-motorik (0-18 bulan); (2) tahap iconic (18 bulan sampai 6 tahun); (3) konkrit simbolik (6 - 16 tahun); (4) tahap formal (16 - 18 tahun); dan (5) tahap post-formal (>18 tahun). Level respons seorang siswa akan berbeda antara suatu konsep dengan konsep lainnya, sehingga respon siswa terhadap tugas-tugas yang sejenis dapat bervariasi. Suatu saat seorang siswa menunjukkan tingkat lebih tinggi, tetapi di saat lain menunjukkan tingkat yang lebih rendah.

Berdasarkan tahap perkembangan mental tersebut, maka terdapat beberapa keterampilan berpikir yang dinilai sesuai dengan tahap usia anak pendidikan dasar menurut National Curriculum (dalam Higgins, 2006). Keterampilan berpikir tersebut mencakup:

1. Keterampilan pemrosesan informasi. Keterampilan yang terkait dengan kemampuan mencari dan mengumpulkan informasi yang relevan, mengurutkan, mengklasifikasikan, membandingkan dan mengkontraskan, serta menganalisis bagian / keseluruhan hubungan.

2. Keterampilan penalaran: Keterampilan yang terkait dengan kemampuan memberikan alasan dari setiap pendapat atau tindakan, menarik kesimpulan dan membuat kesimpulan, menggunakan bahasa yang tepat untuk menjelaskan apa yang mereka pikirkan, dan membuat penilaian dan keputusan berdasarkan alasan atau bukti.

3. Keterampilan inkuiri. Keterampilan yang terkait dengan kemampuan mengajukan pertanyaan yang relevan, mengajukan dan mendefinisikan masalah, merencanakan apa yang harus dilakukan dan bagaimana melakukan penelitian, memprediksi hasil dan mengantisipasi konsekuensi, serta menguji kesimpulan dan meningkatkan ide.

4. Keterampilan berpikir kreatif: Keterampilan yang terkait dengan kemampuan menghasilkan dan memperluas ide, menyarankan hipotesis, menggunakan imajinasi, dan mencari alternatif untuk menghasilkan inovasi.

5. Keterampilan Evaluasi. Keterampilan yang terkait dengan kemampuan mengevaluasi informasi, menilai informasi dari apa yang mereka baca, dengar dan lakukan, mengembangkan kriteria untuk menilai hasil pekerjaan dan ide mereka sendiri serta orang lain berdasarkan keyakinan dalam penilaian mereka. 


\section{Memberdayakan Keterampilan Berpikir: Perspektif Epigenetik dalam Pendidikan}

Pendidikan di sekolah mengambil peran penting dalam perkembangkan hidup siswa. Aktivitas siswa di sekolah (6 jam setiap harinya atau lebih untuk fullday school) berpengaruh terhadap psikologi siswa. Lingkungan belajar yang kondusif, kompetitif dan menyenangkan dapat memfasilatasi siswa dapat mengoptilkan potensi siswa, sehingga siswa menjadi lebih aktif, kreatif dan mampu memecahkan berbagai permasalahan dan tantangan yang mereka hadapi di masyarakat sosial (Afandi dan Sajidan, 2017). Hubungan antar lingkungan, peran keluarga dan jenjang jendidikan dengan keterampilan berpikir HOTs dipaparkan pada gambar 2.

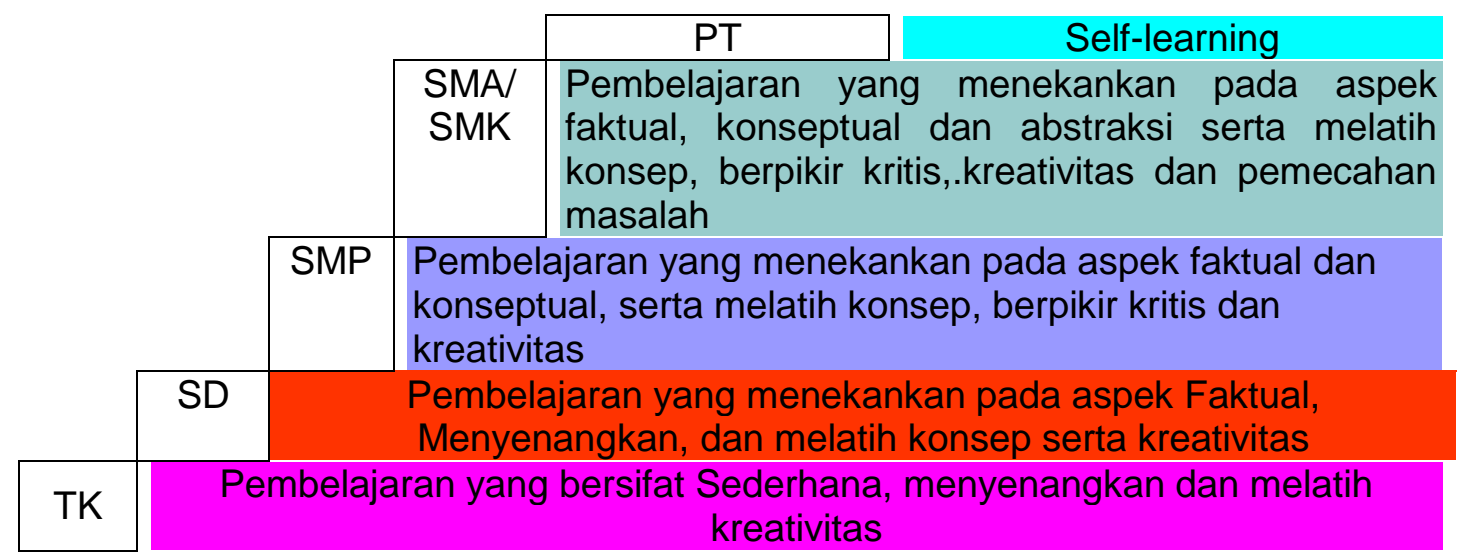

Gambar 2. Hubungan antar lingkungan, peran keluarga dan jenjang

pendidikan dengan HOTs (Sajidan dan Afandi, 2018)

Secara genetik, siswa yang dilatih dengan keterampilan berpikir akan mengalami perkembangan pada tingkat neuralnya. Melatih keterampilan berpikir secara simultan dapat memperkuat sinapsis antar neuron dalam sistem saraf siswa. Hasil penelitian yang dilakukan oleh Song et al (2008) misalnya terhadap 59 anak yang diberikan WAIS IQ test dengan tugas-tugas kognitif yang simultan dan berbeda tingkatan menggunakan MRI menunjukan pola-pola aktivitas otak yang berbeda-beda. Anak yang diberikan tugas kognitif yang stabil hanya mengaktivasi bagian spesifik otak, berbeda halnya dengan anak yang diberikan tugas kognitif yang lebih rumit mampu mengaktivasi secara bersamaan kerja bagian-bagian otak. Hasil penelitian lainnya yang dilakukan oleh Glasher et all (2010) menunjukan bagian-bagian spesifik otak yang berkerja pada organisasi perceptual, pemahaman verbal, kerja memori, dan kecepatan pemrosesan informasi.

Beranjak dari temuan beberapa hasil penelitian diatas, maka pembelajaran yang dapat menstimulasi keterampilan berpikir tingkst tinggi, khususnya keterampilan dalam berpikir kritis, kreatif, dan pemecahan masalah menjadi sangat penting dalam pendidikan dewasa ini. Dryden dan Vos (2016) mengungkapkan terdapat sembilan (9) kerangka baru pembelajaran dalam kaitannya dengan bagaimana nature dan nurture bekerja, yakni: (1) pembelajaran harus memperhatikan genetik/talenta (nature) siswa dan inovasi model pembelajaran; (2) menekankan bagaimana neuroscience bekerja, dalam belajar melibatkan kerja otak, pikiran dan anggota tubuh siswa, untuk membuat pembelajaran lebih mudah, cepat dan lebih efektif. Belajar bagaimana belajar, belajar bagaimana berpikir dan belajar bagaimana berkreasi; (3) guru bertindak sebagai stimulator (tidak didominasi dengan ceramah/orasi/pemasok informasi); (4) menekankan pada pengetahuan science terintegrasi (science integrated learning); (5) menekankan pada learning by doing; (6) mendorong kreativitas dalam menemukan solusi baru, produk-produk baru, ide-ide baru, dan layanan serta pengalaman baru; (7) memberdayakan keterampilan (termasuk HOTs) dan kemampuan; (8) memperkaya pembelajaran dengan keterampilan hidup (lifeskills), termasuk keterampilan 
berkomunikasi dan networking; dan (9) memfasilitasi pembelajaran dengan mendemonstrasikan hasil pengalaman belajar.

Kerangka baru pembelajaran yang disampaikan Dryden dan Vos tersebut kiranya tidak berlebihan jika menilik bahwa keterampilan berpikir harus senantiasa dilatihkan dan guru wajib mempertimbangkan bahwa efek dari nature dan nurture sangat kuat dalam keberhasilan pencapaian hasil belajar siswa. Hasil penelitian riset group IPA dan Pendidikan Program Doktor Pendidikan IPA, FKIP UNS, bahwa model-model pembelajaran inovatif Science Integrated Learning/SIL dapat memberdayakan kemandirian kerja ilmiah peserta didik (Parmin et al, 2017), Inquiry Based Reading/IBR mampu melatihkan keterampilan berargumentasi peserta didik (Probosari et al, 2016), Project Based Scientific Reading/PBSR dapat memberdayakan keterampilan berpikir kritis peserta didik (Suryandari et al, 2018) dan Model pembelajaran Stimulasi HOTs (StimHOTs) berimplikasi kuat dalam pemberdayaan keterampilan berpikir tingkat tinggi (perpikir kritis, kreatif, dan pemecahan masalah) dengan Effect Size (ES) sebesar 0,78 (medium) sampai 1,096 (large) (Sajidan et al, 2017).

\section{Pembelajaran Inovatif Untuk Memberdayakan HOTs Siswa 1. Model Pembelajaran Inquiry}

Pembelajaran inquiry pada dasarnya berakar pada karya John Dewey (18591952), yang percaya bahwa pembelajaran sains harus mengajarkan siswa bagaimana berpikir dan bertindak secara ilmiah (National Research Council, 2000). Pembelajaran inquiry ini kemudian diadopsi dalam skala besar dalam pada 1960-an oleh sejumlah negara untuk mendorong pembelajaran sains secara bermakna. Beberapa pendapat tentang model pembelajaran inquiry, antara lain menurut Widja (1989) adalah suatu model yang menekankan pengalaman-pengalaman belajar yang mendorong siswa dapat menemukan konsep-konsep dan prinsip. Model pembelajaran dengan cara penyajian materi pelajaran yang memberi kesempatan kepada siswa untuk menemukan informasi dengan atau tanpa bantuan guru. Model ini menekankan pada pengalaman belajar yang mendorong siswa untuk dapat menemukan konsep dan prinsip melalui proses mentalnya sendiri.

Inkuiri tidak hanya mengembangkan kemampuan intelektual tetapi seluruh potensi yang ada, termasuk pengembangan emosional dan pengembangan keterampilan. Pada hakikatnya, inkuiri ini merupakan suatu proses. Proses ini bermula dari merumuskan masalah, mengembangkan hipotesis, mengumpulkan bukti, menguji hipotesis, dan menarik kesimpulan sementara, menguji kesimpulan sementara supaya sampai pada kesimpulan yang pada taraf tertentu diyakini oleh peserta didik yang bersangkutan. Ciri utama yang dimiliki oleh model inquiry yaitu menekankan kepada aktivitas siswa secara maksimal untuk mencari dan menemukan jawaban sendiri dari sesuatu yang dipertanyakan sehingga diharapkan dapat menumbuhkan sikap percaya diri (self belief) serta mengembangkan kemampuan berpikir secara sistematis, logis, dan kritis dan mengembangkan kemampuan intelektual sebagai bagian dari proses mental. Tahapan model inkuiri menurut Wening (2011) dipaparkan pada Gambar 3. 

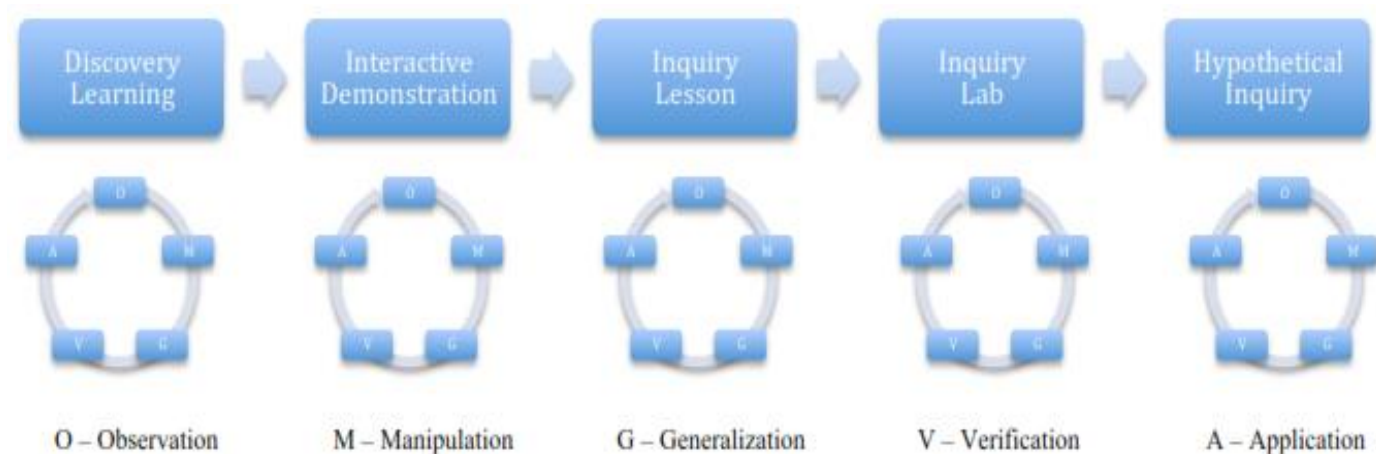

Gambar 3. Tahapan/sintak Model Level of Inquiry menurut Wenning (2011)

a) observation: siswa dihadapkan pada fenomena yang menarik minat dan respon siswa. Siswa mencatat, mendeskripsikan dan menjelaskan secara rinci fenomena yang diamati dan berfikir secara analogi dan memberikan contoh-contoh lain dari fenomena yang diamati.

b) manipulation: siswa menentukan ada/tidak hubungan antar objek atau fenomena yang diamati.

c) generalization: siswa menggeneralisasikan satu atau lebih hubungan antar objek atau fenomena menjadi kesimpulan sementara.

d) verification: siswa mengkomunikasikan kesimpulan sementara kepada teman sekelompok dan kelompok lain untuk diperiksa dan diverifikasi bersama.

e) aplication: siswa mengaplikasikan apa yang telah dipelajari kedalam situasi baru setelah semua kelompok setuju dengan hasil verifikasi.

Pembelajaran berbasis inquiry merupakan pembelajaran dengan strategi berpusat pada siswa (student centered learning), dan mendorong peningkatan literasi dan keterampilan siswa (Gormally, et al. 2009). Wenning lebih lanjut memperkenalkan spektrum inquiry untuk menjelaskan bagaimana proses berpikir kaitannya dengan peran dan tugas guru (Wenning, 2007). Spektrum Inquiry dimulai dari tahap berpikir yang paling sederhana menuju kompleksitas berpikir tingkat tinggi dan digunakan untuk menjelaskan apa yang dilihatnya sebagai variasi model pembelajaran yang secara progresif bergerak dari tingkat kerumitan yang rendah ke kerumitan yang lebih tinggi, dan dari lokus kontrol yang berubah dari guru ke peserta didik (tabel 1)terdiri dari:discovery learning, interactive demonstration, inquiry lesson, inquiry lab (3 tipe guided, bounded, dan free), real-world applications (2 tipe- textbook dan authentic), dan hypothetical inquiry (2 tipe- pure dan applied).

Tabel 1. Spektrum inkuiri Menurut Wenning (2007)

\begin{tabular}{|c|c|c|c|c|c|}
\hline $\begin{array}{l}\text { Discovery } \\
\text { Learning }\end{array}$ & $\begin{array}{c}\text { Interactive } \\
\text { Demonstration }\end{array}$ & $\begin{array}{l}\text { Inquiry } \\
\text { Lesson }\end{array}$ & $\begin{array}{l}\text { Inquiry Lab } \\
\text { (3 types) }\end{array}$ & $\begin{array}{c}\text { Real-world Applications } \\
\text { (2 types) }\end{array}$ & $\begin{array}{c}\text { Hypothetical Inquiry } \\
\text { (2 types) }\end{array}$ \\
\hline Lower & \multicolumn{4}{|c|}{$\leftarrow$ Intellectual Sophistication $\rightarrow$} & Higher \\
\hline Teacher & \multicolumn{4}{|c|}{$\leftarrow$ Locus of Control $\rightarrow$} & Student \\
\hline
\end{tabular}

\section{Children Learning in Science}

Model pembelajaran Children Learning In Science (CLIS) adalah sebuah model yang bertujuan untuk membentuk pengetahuan (konsep) ke dalam memori siswa agar konsep tersebut dapat bertahan lama, karena model pembelajaran CLIS memuat sederetan tahap-tahap kegiatan siswa dalam mempelajari konsep yang diajarkan. Menurut Sutarno (2008), model pembelajaran CLIS memiliki beberapa sintaks, antara lain: 
a. Orientasi (orientation): tahap ini siswa diberikan pertanyaan tentang fenomena alam yang sering dijumpai sehari-hari dalam kehidupan nyata yang ada kaitanya dengan topik meteri.

b. Pemunculan gagasan (elicitation of ideas): tahap ini siswa diberikan suatu permasalahan teka teki untuk mengelaborasi gagasan awal siswa.

c. Penyusunan ulang gagasan (restructuring of ideas): Tahap ini meliputi pengungkapan dan pertukaran gagasan (clarification and excharge), perubahan situasi konflik (exposure of conflict), kontruksi gagasan baru (construction of new ideas), dan evaluasi (evaluation).

d. Penerapan gagasan (application of ideas): tahap ini siswa difasilitasi untuk menjawab pertanyaan yang disusun dalam LKS untuk menerapkan kosep ilmiah mengenai permasalahan dalam kehidupan sehari-hari.

e. Pemantapan Gagasan (review change of ideas): tahap ini siswa diberi kesempatan untuk melakukan refleksi terhadap hasil pembelajaran yang telah diperoleh.

Berdasarkan tahapan-tahapan yang dilaksanakan pada model pembelajaran CLIS maka dapat dikemukakan karakteristik model pembelajaran CLIS antara lain: (1) dilandasi oleh teori belajar konstruktivis, (2) student centered learning (SCL),(3) melakukan aktifitas hands on/minds on, dan (4) menggunakan lingkungan sebagai sumber belajar (Driver et al, 1994). Penelitian tentang deskripsi keterampilan berpikir kritis siswa setelah mengikuti pembelajaran model Children Learning in Science (CLIS) pada materi struktur bumi dan gempa bumi telah dilaporkan oleh Nisak et al (2016), bahwa keterampilan berpikir kritis dengan persentase ketercapaian interpretasi $90 \%$, eksplanasi $80 \%$, analisis $70 \%$, inferensi $50 \%$. Pelaksanaan model pembelajaran CLIS dapat memfasilitasi suasana yang mendorong siswa untuk mengemukakan ide atau gagasan, memberikan kesempatan kepada siswa untuk bertanya pada teman dan guru sehingga mengurangi miskonsepsi, dan memberikan tugas individual yang dikerjakan siswa di rumah berupa pekerjaan rumah sebagai penerapan konsep.

\section{Thinking Activelly in Academic Context (TAAC)}

Model TAAC ini dikembangkan oleh Wallace dan Adams (1993), memiliki delapan tahap: mencari informasi tentang topik, mendefinisikan tujuan pembelajaran, menghasilkan ide-ide baru tentang tujuan, memutuskan ide mana yang lebih relevan untuk mempelajari topik, memverifikasi pembelajaran, menilai cara keterampilan dipraktikkan dan topik dipelajari secara lebih mendalam (secara individu dan dalam kelompok), menyajikan pencapaian yang dicapai dan kesalahan yang dilakukan kelompok dan belajar dari pengalaman (Sanz de Acedo Lizarraga dan Sanz de Acedo Baquedano, 2010). Model TAAC ini dapat dikembangkan menjadi berbagai bentuk sesuai konteksnya, seperti model TASC (Thinking actively in social context) yang menggunakan isu-isu sosial-ekonomi-budaya sebagai stimulan awal, dan TAScS (Thinking actively in science context) yang berlandaskan pada dialektika sains sebagai stimulan proses belajar. Secara rinci, sintesis dari kegiatan yang dilakukan di masingmasing tahapan TAAC disajikan berikut ini.

Tabel 1. Tahapan model TAAC

\begin{tabular}{ll}
\hline Tahap & Aktivitas Guru \\
\hline Mengorganisasikan & $\begin{array}{l}\text { 1. Menghubungkan pengetahuan awal siswa dengan } \\
\text { informasi tentang topik }\end{array}$ \\
$\begin{array}{l}\text { 2. Menspesifikkan terminologi tentang topik yang akan } \\
\text { dipelajari }\end{array}$ \\
$\begin{array}{l}\text { 3endefinisikan Memformulasikan pertanyaan terkait materi } \\
\text { yang ingin dicapai }\end{array}$ & $\begin{array}{l}\text { 1. Mendeskripsikan apa yang harus dipelajari siswa } \\
\text { 2. Menspesifikkan keterampilan berpikir yang ingin } \\
\text { dicapai }\end{array}$ \\
3. Memilih strategi belajar yang tepat untuk belajar
\end{tabular}




\begin{tabular}{|c|c|}
\hline $\begin{array}{l}\text { Menghasilkan sejumlah } \\
\text { ide }\end{array}$ & $\begin{array}{l}\text { 1. Mendorong siswa menghasilkan sejumlah ide tentang } \\
\text { materi yang pelajari } \\
\text { 2. Mendorong siswa menganalisis konten dari berbagai } \\
\text { sudut pandang } \\
\text { 3. Mendorong siswa membuat representasi gambar, } \\
\text { grafik, dan numerik }\end{array}$ \\
\hline $\begin{array}{l}\text { Memutuskan } \\
\text { terbaik }\end{array}$ & $\begin{array}{l}\text { 1. Membimbing siswa dalam menata ide yang akan } \\
\text { didiskusikan } \\
\text { 2. Membimbing siswa dalam memilih ide yang terbaik } \\
\text { 3. Membimbing siswa dalam merencanakan waktu } \\
\text { penyelesaian tugas }\end{array}$ \\
\hline $\begin{array}{l}\text { Memverivikasi } \\
\text { kerja }\end{array}$ & $\begin{array}{l}\text { 1. Memfasilitasi siswa dalam mengobservasi } \\
\text { perkembangan tugas } \\
\text { 2. Mendorong terjadinya evaluasi waktu penyelesaian } \\
\text { tugas }\end{array}$ \\
\hline $\begin{array}{l}\text { Mengkomunikasikan apa } \\
\text { yang dipelajari }\end{array}$ & $\begin{array}{l}\text { 1. Membimbing penyajian hasil kerja individu dan } \\
\text { kelompok } \\
\text { 2. Mendorong siswa dalam menjustifikasi hasil kerja } \\
\text { mereka } \\
\text { 3. Memfasilitasi siswa dalam membandingkan hasil } \\
\text { kerja mereka dengan hasil kerja tim lainnya }\end{array}$ \\
\hline Belajar dari pengalaman & $\begin{array}{l}\text { 1. Mendorong siswa dalam merangkum capaian hasil } \\
\text { kerja } \\
\text { 2. Membimbing siswa melakukan refleksi diri selama } \\
\text { pembelajaran }\end{array}$ \\
\hline
\end{tabular}

\section{SIMPULAN}

Usia anak pada Pendidikan Dasar merupakan usia terbaik dalam pengembangan keterampilan berpikir. Keterampilan ini sangat dipengaruhi oleh lingkungan belajar yang mendukung seperti: iklim kelas, model pembelajaran yang diterapkan guru, dan perilaku guru dalam pembelajaran. Model pembelajaran inovatif seperti inquiry, CLIS, dan TAAC merupakan sedikit dari variasi inovasi pembelajaran untuk melatihkan keterampilan berpikir yang sesuai dengan usia anak Pendidikan Dasar. Guru perlu menggali potensi keterampilan berpikir siswa, menganalisis materi ajar, dan dan mengembangkan HOTs melalui penerapan model pembelajaran yang inovatif.

\section{DAFTAR PUSTAKA}

Afandi dan Sajidan (2017), Stimulasi Keterampilan Berpikir Tingkat Tinggi, Konsep dan Implementasinya dalam Pembelajaran Abad 21, UNS Press.

Biggs, J.B. and Collis, K.E (1982). Evaluating the Quality of Learning: The SOLO Taxonomy. New York: Academic Press.

Budsankom P, Sawangboon, T, Damrongpanit, S and Chuensirimongkol, J. (2015), Factors affecting higher order thinking skills of students: A meta-analytic structural equation modeling study, Educational Research and Reviews Vol. 10(19).

Clark, L. D., Boutroz, N. N., \& Mendez, F. M. (2010). Brain and Behaviour. New York: Cambridge Univeristy Press

Driver, R., Asoko, H., Leach, J., Mortimer, E., \& Scott, P. (1994). Constructing scientific knowledge in the classroom. Educational Researcher, 23 (7), 5-12

Dryden, G dan Vos, J. (2016). The New Learning Revolution: How Brain Can Lead The World in Learning, Education, and Schooling. New Zealand: The Learning Web 
Glascher, J., Rudrauf, D., Colom, R., Paul, L. K., Tranel, D., Damasio, H. \& Adolphs, R. (2010). Distributed neural system for general intelligence revealed by lesion mapping. Proceedings of the National Academy of Sciences of the United States of America, 107, 4705-4709.

Gormally, C., Brickman, P., Hallar, B., and Armstrong, N (2009) "Effects of Inquirybased Learning on Students' Science Literacy Skills and Confidence. International Journal for the Scholarship of Teaching and Learning. 3(2):16

Gutman, L. M., \& Feinstein, L. (2008). Children's Well-Being in Primary School: Pupil and School Effects. Centre for Research on the Wider Benefits of Learning Institute of Education

Higgins, S. (2006). Developing Thinking Skills in the Primary Classroom. Paper presented at the Register of Primary Research Seminar Conference

Holyoak, J. K \& Morrison, G. R. (2005). The Cambridge handbook of thinking and reasoning. New York: Cambridge Univeristy Press

Lundervold, A. J., Heiman, M., \& Manger, T. (2010). Behaviour-emotional characteristics of primary-school children rated as having language problems. British Journal of Educational Psychology. 78(4): 567-580

McGregor, D. (2007). Developing thinking; developing learning: A Guide to developing thinking in education. New York: Open University Press

National Research Council. (2000). Inquiry and the national science standards. Washington, DC: National Academy Press.

Nisak, Z. K. (2016). Penerapan Model Pembelajaran Children Learning In Science (CLIS) Untuk Melatihkan Keterampilan Berpikir Kritis Siswa SMP. Jurnal Pendidikan Sains, 4(1)

Parmin, Sajidan, S. Ashadi, A. Sutikno, Fibriana, F, (2017), Science Integrated Learning Model to Enhance The Scientific Work Independence of Student Teacher in Indigenous Knowledge Transformation, Indonesian Journal of Science Education, Vol 6, No 2.

Pinel, J. P. (2000). Biopsychology. Needham Height: Pearson Education Company.

Probosari,R.M, Sajidan S, Suranto S, Prayitno B.A, Ramli,M , Sulistyawati, H. (2016), Constructing Scientific Argumentation in Inquiry Based Reading : Frameworks for Analyzing Argument Process in the Classroom, Proceeding The 2nd International Conference On Teacher Training and Education, Sebelas Maret University Volume 2 Nomor 1.

Sajidan, Masykuri, M., dan Prayitno, B. A. (2017). Pengembangan Model Pembelajaran IPA untuk Memberdayakan Keterampilan Berpikir Tingkat Tinggi Peserta Didik, Laporan Penelitian, PNBP LPPM UNS Tahun I.

Sajidan dan Afandi. (2018). Memberdayakan Keterampilan Beripikir Tingkat Tinggi: Tinjauan Epigenetik dan Implikasinya dalam Pendidikan. Disampaikan dalam Seminar Nasional Pendidikan IPA UNNES, 22 April 2018

Sanz de Acedo Lizarraga, M. L, Sanz de Acedo Baquedano, M. T and Oliver, M.S. (2010). Stimulation of thinking skills in high school students. Journal Educational Studies, 36(3)

Schunk, H. D. (2012). Learning theories. An Educational Perspective (terjemahan). Yogyakarta: Pustaka Pelajar

Sutarno, N. (2008). Materi dan Pembelajaran IPA SD. Jakarta: Universitas Terbuka

Song, M., Liu, Y., Zhou, Y., Wang, K., Yu, C. \& Jiang, T. (2009). Default network and intelligence difference. Conference Proceedings of the IEEE Engineering in Medicine and Biology Society, 2009, 2212-2215.

Suryandari, K,C, Sajidan, Rahardjo, S.B., and Prasetyo, Z.,K.,(2018), The Beliefs towards Science Teaching Orientation of Pre-service Teachers in Primary Teacher Education Programme, Pertanika J. Soc. Sci. \& Hum. 25 (S): 169 - 186 
Teare, B. (2005). Effective resources for able \& talented children. New York: Continuum International Publishing Group

Wallace, B. and Adams, H. B. (1993) TASC. Thinking Actively in a Social Context. Bicester: A. B. Academic Publishers.

Wenning, C. J. (2007). Assessing inquiry skills as a component of scientific literacy, J. Phys. Tchr. Educ [Online], 4(2), 21-24

Wenning, C. J. (2011). The levels of inquiry model of science teaching, J. Phys. Tchr. Educ. [Online], 6(2),9-16

Widja, I Gede. 1989. Dasar-Dasar Pengembangan Strategi serta Model-Model Pengajaran Sejarah. Jakarta: Depdikbud Dirjen Dikti.

Woolfolk, A. (2009). Educational psychology: Active learning (10th Edition). Yogyakarta: Pustaka Pelajar

Zohar, A. (2004). Higher order thinking in science classroom: Students' learning and teachers' professional development. UK: Springer-Science + Business Media B.V 